\title{
Mothers and their Children as Victims in War: Amos 1:13 against the Background of the Ancient Near East
}

\author{
Paul A. Kruger (University of Stellenbosch)
} ABSTRACT

This article investigates a war atrocity mentioned in Amos 1:13, viz. "ripping open pregnant women." Twice the combination "ripping open pregnant women" appears in close proximity with "dashing in pieces the little ones" (2 Kgs 8:12; Hos 14:1). The latter topic is also occasionally referred to in other prophetic passages (Isa 13:16; Nah 3:10). After the presentation of comparable evidence from a variety of ANE literary genres, it is concluded that these types of literary topoi were not essentially meant to convey a historical truth. They were rather employed as rhetorical devices to amplify the seriousness of the given (war) scenario.

KEYWORDS: Amos; War Atrocities; Literary Devices, Historical Inquiry, Literary Analysis.

\section{A INTRODUCTION}

In recent times there has been an upswing in investigations regarding war and war atrocities in the ANE, especially acts committed against different groups in society such as women, ${ }^{1}$ children ${ }^{2}$ and elderly people, ${ }^{3}$ as well as against nature ${ }^{4}$ and sacred institutions. ${ }^{5}$ Amos 1-2 are among those texts in the HB that

* Article submitted: 3/12/2015; article accepted: 9/02/2016. Paul A. "Kruger, Mothers and Their Children as Victims in War: Amos 1:13 Against the Background of the Ancient Near East," OTE 29/1 (2016): 100-115. DOI: http://dx.doi.org/10.17159/2312 $-3621 / 2016 / v 29 n 1 a 7$

1 Paul A. Kruger "Women and War Brutalities in the Minor Prophets: The Case of Rape,"OTE 27/9 (2014): 147-176.

2 Andreas Michel Gott und Gewalt gegen Kinder im Alten Testament (FAT 37; Tübingen: Mohr Siebeck, 2003).

3 Andreas Michel, “Texts of Terror für Alte? Gewalt gegen ältere Menschen im Alten Testament," in Macht-Gewalt-Krieg im Alten Testament: Gesellschaftliche Problematik und das Problem ihrer Repräsentation (ed. Irmtraud Fischer; QD 254; Freiburg: Herder, 2013), 53-82.

4 Michael G. Hasel, “Assyrian Military Practices and Deuteronomy’s Laws of Warfare," in Writing and Reading War: Rhetoric, Gender, and Ethics in Biblical and Modern Contexts (ed. Brad E. Kelle and Frank R. Ames; SBLSymS 42; Atlanta: Society of Biblical Literature, 2008), 67-81. 
describe several forms of such war actrocities. Often these violent deeds are given a name, such as "sending (שלח; pi el) fire" (1:4, 7, 10, 12; 2:2, 5), "deporting (גלה; hip il) communities" (1:6), "ripping open (בקע) pregnant women" (1:13) and "burning (שרף) the bones of the dead" (2:1). On other occasions, though, the war atrocity is depicted in an ambiguous way as in 1:3 ("threshing Gilead with threshing sledges of iron") and hence the question arises whether such descriptions should be taken in a literal or metaphoric sense. Some regard these accounts as references to real historical circumstances, ${ }^{7}$ while others provide a different Sitz im Leben. ${ }^{8}$ Ancient Near Eastern

5 Walter Mayer, "Die Zerstörung des Jerusalemer Tempels 587 v.Chr. im Kontext der Praxis von Heiligtumszerstörungen im antiken Vorderen Orient," in Zerstörungen des Jerusalemer Tempels: Geschehen-Wahrnehmung-Bewältigung (ed. Johannes Hahn; WUNT 147; Tübingen: Mohr Siebeck, 2002), 1-22. Other most recent general surveys on ANE war practices include: Hans Neumann, et al., eds., Krieg und Frieden im Alten Vorderasien: 52e Rencontre Assyriologique Internationale: International Congress of Assyriology and Near Eastern Archaeology, Münster, 17.-21. Juli 2006 (AOAT 401; Münster: Ugarit-Verlag, 2014) and Davide Nadali and Jordi Vidal, eds., The Other Face of the Battle: The Impact of War on Civilians in the Ancient Near East (AOAT 413; Münster: Ugarit-Verlag, 2014).

6 See e.g. Walter Mayer, "Gedanken zur Deportation im Alten Orient," in Macht und Herrschaft (ed. Christian Sigrist; AOAT 316; Münster: Ugarit-Verlag, 2004), 215-232.

7 Cf. the remark by Herbert Werner, Amos (ExBib 4; Göttingen: Vandenhoeck \& Ruprecht, 1969), 61: "Er bestand vielleicht darin, dass sich die bei diesem Einfall gemachten Gefangenen nebeneinander auf dem Boden ausstrecken mussten, um elendlich dadurch zu Tode geschunden zu werden, dass eiserne Dreschschlitten oder eigens zu diesem Zwecke konstruierte, mit eisernen Schneiden oder Zacken versehene Walzen über sie hingezogen wurden."

8 Such as the LXX, which has an addition and a different interpretation. Instead of "because they have threshed Gilead with sledges of iron teeth" (MT), it has: "because they were sawing ( $\left.\varepsilon^{\prime} \pi \rho \zeta_{0 \nu}\right)$ pregnant women of those in Galaad asunder with iron saws" (NETS). The first part, "saw with iron saws" has a similar construction in LXX 1 Chr 20:3. There it is said of David that "he brought out the people who were in it (=

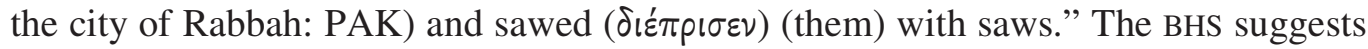
that instead of the relatively rare verb שור ("to tear asunder"?), שים ("to set"), which is attested in the parallel passage 2 Sam 12:31, should be read: "he set (שים) (them) to labour with the saw and iron picks." But Gary N. Knoppers, 1 Chronicles 10-29 (AB; New York: Doubleday, 2004), 730, opts for the lectio difficilior reading (שור: "to tear asunder") and takes the implied object "it" as the city and not the people, as the LXX does: "After he brought out the people who were in it, he tore (it) asunder with a saw..."; see Knoppers, 1 Chronicles 10-29, 728. Sara Japhet, 1 Chronik (HTKAT; Freiburg: Herder, 2002), 332, offers a different translation for the first part: "Und auch das Volk, das in ihr war, führte er heraus und stellte sie zur Arbeit an der Säge ...," but makes the remark: "Bedeutet die Verbform וישר tatsächlich >> er liess sie zersägen $<<$, was eine brutale Folter wäre, oder handelt es sich um Sägen als Zwangsarbeit? Linguistisch muss the Frage unentschieden bleiben"; see Japhet, 1 Chronik, 
war texts passages, however, testify to the fact that the "threshing image" is rather to be seen as a fossilised topos conveying in a figurative manner complete destruction as a consequence of war. Compare, for instance, the following example in The Summary Inscription 1 from Calah (Tiglath-Pileser III). The text runs: "Bit-Amukkani I threshed (dâšu: PAK) as though with a threshing sledge. All of its people, its property, I took to Assyria" (lines 11-12). ${ }^{9}$ On another occasion Tiglath-Pileser III boasts about something similar: "Like a threshing sledge, I trampled down the lands . . ."10 Compare also the following threat in the curse formulae of Esarhaddon's Succession Treaty: "May Šamaš with an iron plough [overtu]rn yo[ur] city and your district." 11

In Amos 1-2, however, the nature of some war atrocities is quite specific, as in 1:13, "the ripping open (בקע) of pregnant women" and in 2:1, "the burning (שרף) the bones of the dead." These crimes should certainly count among the most brutal, since by committing them it is not just the rights of the living (pregnant women and their unborn babies) that are violated, but also those of people long dead. ${ }^{12}$ In this contribution I will focus only on the first atrocity, namely the fate of mothers (Am 1:13). Obviously one could not understand the predicament of pregnant mothers in war situations without taking into account the plight of their children at the same time. That these two cruel deeds could not be separated from one another is clearly testified by 2 Kgs 8:12 and Hos 14:1, where "dashing in pieces the little ones" (שט appears in close proximity to "ripping open (בקע) pregnant women."

339. According to W. Edward Glenny, Finding Meaning in the Text: Translation Technique and Theology in the Septuagint of Amos (VTSup 126; Leiden: Brill, 2009), 157, the addition "pregnant women" in LXX Amos 1:3 is perhaps influenced by (1) the "pregnant women of the Gileadites" in v. 13, or (2) it could give evidence of the fulfillment of the words of Elisha in $2 \mathrm{Kgs} \mathrm{8:12,} \mathrm{where} \mathrm{the} \mathrm{prophet} \mathrm{foretells} \mathrm{that} \mathrm{Hazael,}$ king of Aram, will "rip open the pregnant women" of Israel.

9 Translation is by Hayim Tadmor, The Inscriptions of Tiglath-Pileser III King of Assyria: Critical Edition, with Introductions, Translations and Commentary (Jerusalem: The Israel Academy of Sciences and Humanities, 1994), 123.

10 Text 40:11; for the translation, cf. Hayim Tadmor and Shigeo Yamada, The Royal Inscriptions of Tiglath-Pileser III (744-727 BC), and Shalmaneser V (726-722 BC), Kings of Assyria (RINAP 1; Eisenbrauns: Winona Lake, 2011), 100.

11 Par 68, 545; Simo Parpola and Kazuko Watanabe, Neo-Assyrian Treaties and Loyalty Oaths (SAA 2; Helsinki: Helsinki University Press, 1988), 51; see also 2 Kgs 13:7.

12 Cf. Erasmus Gass's remark regarding Amos 2:1 in Erasmus Gass, Die Moabiter: Geschichte und Kultur eines ostjordanischen Volkes im 1. Jahrtausend v. Chr. (ADPV 38; Wiesbaden: Harrassowitz, 2009), 157: "Auf alle Fälle bildet dieses Verbrechen an einem Toten (Am 2:1: PAK) das thematische Gegenstück zum Verbrechen der Ammoniter an Lebenden, die nach Am 1,13 schwangere Frauen aufgeschlitzt hätten." 


\section{B RIPPING OPEN PREGNANT WOMEN AND DASHING IN PIECES LITTLE ONES}

Women and children were an essential part of siege warfare. Their presence threatened the notion of war as a conquest between warriors, undermined the conventional standards of honor and prowess that governed ancient warfare, and paradoxically made war less restrained by creating a morally chaotic cityscape in which not only the walls collapsed but deeply rooted social and moral distinctions as well. We cannot understand siege warfare without understanding the plight of women and children and the effect of their presence on war. $^{13}$

This general assessment regarding the devastation of siege warfare, involving all levels of society, especially that of women and children, is corroborated by ANE and HB evidence. Often we hear that war has no favourites, no one is spared, not even women or children. It simply was not "a conquest between warriors" (those "outside"), but it also affected the most vulnerable in society (those "inside"), as is vividly depicted in Deut 32:25: "Outside the sword will make childless and inside terror: the young man (בחור) and virgin (בתולה) alike, the nursing child (יונק) and the grey-haired man (איש שיבה)." What is striking here is acknowledgement of the fact that in war there is "no age restriction": the youngest (יונק) as well as the oldest (איש שיבה) are victims. This inclusiveness is echoed by several HB texts - for example, in the Deuteronomistic History, Josh 6:21, where it is said: "They observed the ban with the sword to all which was in the city, from men and women, young (נער) and old (זקן), as well as oxen, sheep and donkeys." Or in the prophetic literature, where Jeremiah, because of the obstinacy of Jerusalem, could no longer contain the wrath of Yahweh, crying out: "Pour it out upon the children (עולל) in the street (בחוץ), and upon the circle of young men (בחורים). Man as well as woman shall be taken, the elderly (זקן) and those advanced in years (מלא ימים)" (Jer 6:11). The same theme resonates in the Book of Lamentations (2:21): "On the ground in the streets (זוצות) lie young (נער) and old (זקן); my young women (בתולתי) and my young men (בחורי) have fallen by the sword."14 In like manner, Ashurbanipal boasts in his war annals that he spared no one, but killed "young and old":

Die Einwohner von Sais, Mendes, Pelusium, soviele sich zu ihnen gesellt und Böses geplant hatten - klein und gross streckten sie mit

13 Paul B. Kern, Ancient Siege Warfare (Bloomington: Indiana University Press, 1999), 187.

14 See Rüdiger Lux, "Die Kinder auf der Gasse: Ein Kindheitsmotiv in der prophetischen Gerichts- und Heilsverkündigung," in "Schaffe mir Kinder ...": Beiträge zur Kindheit im alten Israel und in seinen Nachbarkulturen (ed. Andreas Kunz-Lübcke and Rüdiger Lux; ABG 21; Leipzig: Evangelische Verlagsanstalt, 2006), 205. 
104 Kruger, "Mothers and their Children," OTE 29/1 (2016): 100-115

den Waffen nieder, keinen einzigen Menschen liessen sie dort übrig. Ihre Leichen hängten sie an Pfählen auf. Sie zogen ihnen die Haut ab und bekleideten damit die Stadtmauer. ${ }^{15}$

Other motifs, specifically affecting women and children, are likewise alluded to in so-called "siege texts." 16 These include: "the mother barring her door to her daughter"17 and "teknophagy." 18 In his study Michel compiled a variety of texts types from the HB reflecting the predicament of children in war contexts. He lists the following categories: (1) "Children as the Victims of Military Combats, through Starvation, Drowning or Wild Animals"; (2) "Extermination of a Dynasty"; (3) "Destitution due to a Siege: Teknophagy"; and (4) "Children as War Booty, Prisoners of War/Slaves; Robbery of Women."19 As far as the Minor Prophets are concerned, only the following texts are cited and they all belong to the first category, namely "Children as the Victims of Military Combats": Hos 10:14, 14:1, Amos 1:13, 7:17 and Nah 3:10.

But before taking a closer look at this last type ("Children as the Victims of Military Combats"), especially concerning Amos 1:13, it is useful to turn to the Assyrian data to establish how children and their mothers were treated in similar situations. Two kinds of information are available: Assyrian art and the Assyrian royal inscriptions. In the former children and their mothers are mostly portrayed as deportees. No one is shown to be mistreated. ${ }^{20}$ Mothers act in capacities typical of motherhood: children are breast-fed, carried on the arms,

15 Prism C II 130-III 5; see Rykle Borger, Beiträge zum Inschriftenwerk Assurbanipals (Wiesbaden: Harrassowitz, 1996), 214.

16 For a discussion of this genre of texts, cf. A. Leo Oppenheim, "Siege-Documents from Nippur," Iraq 17 (1955): 69-89.

17 For this topos, see Oppenheim, "Siege-Documents," 72-78 and Michel, Gott und Gewalt, 205, 207.

18 Michel, Gott und Gewalt, 39, 200. For an example of this regarding Ashurbanipal (Prism A IX 58-59), see Borger, Beiträge, 248, and Robert Rollinger, "Herodotus, Human Violence and the Ancient Near East," in The World of Herodotus (ed. Vassos Karageorghis and Ioannes Taifacos; Nicosia: Kailas, 2004), 141. The theme of teknophagy is also most pertinent in Lamentations (2:20 and 4:10).

19 Michel, Gott und Gewalt, 31.

20 See Pauline Albenda, "Woman, Child, and Family: Their Imagery in Assyrian Art," in La Femme dans le Proche-Orient Antique: Compte Rendu de la XXXIII Rencontre Assyriologique Internationale, Paris, 7-10 Juillet 1986 (ed. Jean-Marie Durand; Paris: Editions Recherche sur les Civilisations, 1987), 17. See, however, one case (Relief BM 124927 found in the North Palace of Nineveh) where women from an Arabic nomadic group are depicted as being hit and apparently also being raped; cf. Thomas Staubli, Das Image der Nomaden im Alten Israel und in der Ikonographie seiner sesshaften Nachbarn (OBO 107; Fribourg: Academic Press, 1991), 93-94; see also Peter Dubovský, "Ripping Open Pregnant Arab Women: Reliefs in Room L of Ashurbanipal's North Palace," Or 78/3 (2009): 394-419. 
or the shoulders. ${ }^{21}$ In the inscriptions, however, the picture is different: children (adolescent boys and girls) were frequently mentioned as being "burnt" by the Assyrian king. Compare the following passage describing the capture of the city of Tēla by Ashurnasirpal II (A.0.101.1 i 113-ii 1). Here a clear distinction is made between the treatment of captivated soldiers and children:

I approached the city of Tēla. The city was well fortified; it was surrounded by three walls. The people put their trust in their strong walls and their large number of troops and did not come down to me (i 115). They did not submit to me. In strife and conflict I besieged (and) conquered the city. I felled 3,000 of their fighting men with the sword. I carried off prisoners, possessions, oxen, (and) cattle from them. I burnt many captives from them. I captured many troops alive: from some I cut off their arms (and) hands; from others I cut off their noses, ears, (and) extremities. I gouged out the eyes of many troops. I made one pile of the living (and) one of heads. I hung their heads on trees around the city. (ii 1) I burnt their adolescent boys and girls. I razed, destroyed, burnt, (and) consumed the city. $^{22}$

But of all the cruel deeds committed in the context of war, the "dashing in pieces (רטש) (עלל), (24 $^{23}$ the little ones alluded to a few times in the HB, must certainly have been the most brutal. It is reported as a war practice in $2 \mathrm{Kgs}$ 8:12 (against Hazael of Damascus), in Isa 13:16 (against Babylon), in Hos 14:1 (against Israel), and in Nah 3:10 (against Thebes). Twice this combination appears in close connection with another equally brutal war atrocity, viz. "rip-

21 See Albenda, "Woman, Child, and Family," 17 and Irène Schwyn, "Kinder und ihre Betreuungspersonen auf den neuassyrischen Palastreliefs," in Images and Gender: Contributions to the Hermeneutics of Reading Ancient Art (ed. Silvia Schroer; OBO 220; Fribourg: Academic Press, 2006), 323-330.

22 Italics in the second last sentence added; for the translation, see A. Kirk Grayson, Assyrian Rulers of the Early First Millennium BC I (1114-859 BC) (RIMA 2; Toronto: University of Toronto Press, 1991), 201. For other examples in the same vein, see Rollinger, "Herodotus," 141, n. 21. It may be that the following curse (Par 96A, 636A) in Esarhaddon's Succession Treaty reflects in similar manner to what extremes the Assyrians could go: "may they [slaughter] you, your women, your brothers, your sons, and your daughters like a spring lamb and kid"; cf. Parpola and Watanabe, Neo-Assyrian Treaties, 57.

23 Michel, Gott und Gewalt, 108, convincingly argues that the root רטש is a technical term for violence against children in war situations.

24 According to Magnus Saebo, "עול," ThWAT 5: 1133: “. . . die Erwähnung von 'Kleinkind' ('ôlel/'ôlāl; PAK) . . . scheint eine Redeweise in Kriegs- und Notschilderungen zu sein, die die Grausamkeit des Krieges und die tiefe Not des Volkes unterstreicht." See also Michel, Gott und Gewalt, 24, n. 28. 
ping open (בקע) pregnant women"; 25 once in combination with the "plundering of houses" (שסס; nip 'al) and the "raping" (שגל; nip 'al) of wives (Isa 13:16), and once in association with the "casting (ידד) of lots" for honoured men and the "binding" (רתק; pu'al) in chains of dignitaries (Nah 3:10). ${ }^{27}$ Strangely enough, no trace is found of either of these motifs ("ripping open pregnant women"; "dashing in pieces the little ones") in Assyrian war accounts.

Apart from these occurrences, the combination "ripping open pregnant women" occurs twice more: once as part of a narrative report regarding king

$252 \mathrm{Kgs} \mathrm{8:12:} \mathrm{"You} \mathrm{will} \mathrm{set} \mathrm{their} \mathrm{fortresses} \mathrm{on} \mathrm{fire} \mathrm{and} \mathrm{you} \mathrm{will} \mathrm{kill} \mathrm{their} \mathrm{young} \mathrm{men}$ with the sword, dash in pieces (רטש: pi el) their little ones (עלל) and rip open (בקע); pi 'el) their pregnant women"; Hos 14:1: "Samaria shall bear the guilt, because she rebelled against her God. They will fall by the sword; their little ones (עלל) shall be dashed in pieces (רטש; pu'al) and their pregnant women be ripped open (בקרל); pu 'al)."

26 Isa 13:16: "Their little ones will be dashed in pieces before their eyes; their homes plundered and their wives ravished." Ulrich Berges and Bernd Obermayer, "Gottes Gewalt gegen Kinder in den Büchern Jesaja und Klagelieder: Eine Bibeltheologische Problemanzeige," in Gewalt im Spiegel alttestamentlicher Texte (ed. Norbert C. Baumgart and Martin Nitsche; ErTS 43; Würzburg: Echter Verlag, 2012), 60-61, hold that with this cruel act committed against children in the presence of adults ("before their eyes") "ist der absolute Tiefpunkt der Grausamkeit erreicht. . . . So wird nicht nur das Leben der künftigen Generation zerstört, sondern auch das der jetzigen."

27 Nah 3:10: "She too went into exile; her little ones were dashed in pieces (שטש; pu' $a l$ ) at the corner of every street; for their honoured men lots were cast, and all her dignitaries were bound in chains." In two other texts the root רטש is likewise attested, but there the subject/object is different: "Bows will dash young men in pieces (רטש; pi 'el); they will have no compassion on the fruit of the womb; their eyes will not pity children" (Isa 13:18). The LXX understands the "bows" as a status constructus: "they will dash in pieces the bows of the young men"; see Michel, Gott und Gewalt, 33, nr. 61. In Hos 10:14 the mother is "dashed in pieces" (רטש; pu 'al) "upon" (על) the children," whatever this statement may refer to. The usual translation here is: "a mother is dashed in pieces with her children," but more preferable is the rendering "mother upon the children" to heighten the cruelty of the act. The same motif is alluded to in Ps 137:9, but instead of the technical term נפט ("smash"; pi 'el) is used: "Blessed will be the one who seizes and smashes (נפץ) your little ones against the rock." The apparently superfluous "on the rock" (which is unique in the HB with respect to this act) may serve to intensify the horror of the act. "The rock may signify that the blood is visible to all"; see Shimon Bar-Efrat, "Love of Zion: A Literary Interpretation of Psalm 137," in Tehillah le-Moshe: Biblical and Judaic Studies in Honor of Moshe Greenberg (ed. Mordechai Cogan, Barry L. Eichler and Jeffrey H. Tigay; Winona Lake: Eisenbrauns, 1997), 9. For a literary-critical analysis of this passage, see Michel, Gott und Gewalt, 162-176. For a discussion of the history of interpretation of v. 9, see Siegfried Risse, "Wohl dem, der deine kleinen Kinder packt und sie am Felsen zerschmettert': Zur Auslegungsgeschichte von Ps 137,9," BibInt 14 (2006): 364-384. 
Menahem of Israel against the rebellious city of Tiphsah $(2 \mathrm{Kgs} 15: 16)^{28}$ and once as part of a prophetic speech in Amos 1:13 (Ammon against Gilead). ${ }^{29}$ As in the case of the related theme, "the dashing in pieces the little ones," we are confronted with the problem of the historical trustworthiness of the statement about pregnant women. What is the status of such reports? Some consider them as historically reliable, typical manifestations of "psychological warfare" as practised within a Syro-Palestinian milieu:

Im Hinblick auf die hinter dem Dargestellten aufscheinende Realität spricht manches dafür, das wir mit dem Zerschmettern von Kleinkindern und dem Aufschlitzen von Schwangern nicht nur Topoi, sondern ältere Kriegspraktiken der syro-palästinischen Staatenwelt ... vor uns haben, die aber auch auf die Seite der psychologischen Kriegsführung gehören. ${ }^{30}$

Others, though, are of a different view and claim that such scenarios are intended to serve propagandistic or ideological purposes. Compare the following claim advanced by Tuor-Kurth, who defends the affective purpose of such statements:

Mir scheint aber deutlich, dass die biblischen Texte solche Handlungen auch deshalb als feindliche Stereotypen anführen, um deren Gottlosigkeit herauszustreichen. ${ }^{31}$

28 "Then Menahem smote Tiphsah and all who were in it and its territory from Tirzah. Because they did not surrender, he attacked (the city); he ripped open (בקע; pi el) all its pregnant women." Mordechai Cogan and Hayim Tadmor, II Kings: A New Translation with Introduction and Commentary (AB 11; New York: Doubleday, 1988), 171, regard "the ripping open of pregnant women" as a "critical comment of a later editor $\left(\operatorname{Dtr}_{1}\right.$ ?), who recorded that Menahem in his battle at Tappuah (Tiphsah: PAK) behaved as cruelly as the Aramaeans" (see 2 Kgs 8:12).

29 "Thus says the Lord because of three transgressions of the Ammonites, and for four I will not revoke it (punishment: PAK), because they ripped open (בקע) the pregnant women of Gilead in order to enlarge their territory."

30 Andreas Michel, "Gewalt gegen Kinder im alten Israel: Eine sozialgeschichtliche Perspektive," in "Schaffe mir Kinder. . .": Beiträge zur Kindheit im alten Israel und in seinen Nachbarkulturen (ed. Andreas Kunz-Lübcke and Rüdiger Lux; ABG 21; Leipzig: Evangelische Verlagsanstalt, 2006), 146.

31 Christina Tuor-Kurth, Kindesaussetzung und Moral in der Antike: Jüdische und christliche Kritik am Nichtaufziehen und Töten neugeborener Kinder (FKDG 101; Göttingen: Vandenhoeck \& Ruprecht, 2010), 117; cf. also Angelika Berlejung, "Erinnerungen an Assyrien in Nahum 2, 4-3, 19," in Die unwiderstehliche Wahrheit: Studien zur alttestamentlichen Prophetie: Festschrift für Arndt Meinhold (ed. Rüdiger Lux and Ernst-Joachim Waschke; ABG 23; Leipzig: Evangelische Verlagsanstalt, 2006), 340, with regard to the "dashing of little ones" in Nah 3:10: "Der in V. 10 erzählte Kindermord findet in dieser Form in assyrischen (oder auch babylonischen) Quellen keine Entsprechung ... und scheint eher auf einen allgemeinen Topos der 
To testify to the literary and formulaic nature of such motifs, the following instances, gathered from a range of ANE texts, may be briefly noted. The horrific deed of biblical Menahem (2 Kgs 15:16) referred to above reminds one of another despotic tyrant described in a Middle Assyrian heroic poem (VAT 13833). ${ }^{32}$ As in the case of Menahem, a connection is made between the "ripping open of pregnant women" and the fate that will befall their children. The relevant text part runs: "He slits the wombs of pregnant women; he blinds the infants. He cuts the throats of their strong" (Rev 3-4). ${ }^{33}$ The uniform formulation of the cruelties "may suggest that a fixed literary form was being employed to portray an unspeakable outrage." 34

In other contexts, too, similar fixed formulae are encountered to emphasise the heinous actions of tyrants, one of which is often the violation of women and the heartless treatment of children. ${ }^{35}$ Compare, for example, the following picture of the cruelty of the tyrant, Antiochus Epiphanes, concerning two women who refused to take part in the pagan cult: "For two women who circumcised their sons were hauled up (for punishment): they hung their babies from their breasts and then, after parading them publicly around the city, flung them from the wall" (2 Macc 6:10). ${ }^{36}$

Similar topoi still persist in much later times. During the colonisation of America in the sixteenth century the bishop of Chiapas, Bartolomé de Las

Feinddiffamierung und der Ausmalung der Kriegsgräuel . . . zurückzugehen.” For a similar view, see Lux, "Die Kinder auf der Gasse," 205, nr. 41, and Volkmar Fritz, "Die Fremdvölkersprüche des Amos," VT 37 (1987): 31: "Auch bei dieser Aussage handelt es sich um einen Topos, der im Orient allgemein verbreitet war und die totale Vernichtung des Feindes beschreibt."

32 See Mordechai Cogan, "'Ripping Open Pregnant Women' in Light of an Assyrian Analogue," JAOS 103/4 (1983): 755-757. According to Cogan, “'Ripping Open," 755 , the unnamed hunter probably refers to Tiglath-Pileser I (1114-1076 B.C.E.).

33 For the translation, see Cogan, "'Ripping Open,"” 756.

34 Cogan, “'Ripping Open,"” 755. See also Wilfred G. Lambert, “A Neo-Babylonian Tammuz Lament," JAOS 103/1 (1983): 212, who refers to another example from a Neo-Babylonian lament spoken by Ištar where one of the lines (Line 19) runs: “. . . my eyes cannot look on my ... the ripping open of mothers' wombs" and comments that the phrase seems "to allude to invasion by an enemy army"; Lambert, "Neo-Babylonian," 214; see also Ruth Poser, Das Ezechielbuch als Trauma-Literatur (VTSup 154; Leiden: Brill, 2012), 195.

35 On the peculiarities of despots/tyrants, see Walter Ameling, "Tyrannen und schwangere Frauen," Historia 45 (1986): 507-8 and John G. Gammie, "Herodotus on Kings and Tyrants: Objective Historiography or Conventional Portraiture?" JNES 45/3 (1986): 171-195.

36 The translation is by Daniel R. Schwartz, 2 Maccabees (CEJL; Berlin: De Gruyter, 2008), 270; see also the parallel in 1 Macc 1:61 and Tuor-Kurth, Kindesaussetzung, 117. 
Casas, presented the following short overview entitled "Brevísima relación de la destruición de las Indias" ("A Very Short Record of the Destruction of the West Indies"). It was published in 1552 and the atrocities believed to be committed read like an excerpt from ANE war reports:

Die Christen mit ihren Pferden, Schwertern und Lanzen verübten Metzeleien und unerhörte Grausamkeiten an ihnen. Sie drangen in die Ortschaften ein; sie verschonten nicht einmal Kinder oder Greise, Schwangere oder Wöchnerinnen; ihnen allen schlitzen sie den Bauch auf und zerstückelten sie, als fielen sie über ein paar Lämmer her, die in ihren Hürden eingesperrt wären. Sie schlossen Wetten ab, wer mit einem einzigen Hieb einen Menschen zweiteilen oder ihm den Kopf mit einem Pikenstoss abtrennen oder ihm auch die Eingeweide aufreissen könne. Sie zerrten die neugeborenen Kinder von der Mutterbrust, packten sie an den Beinen und zerschlungen ihnen den Kopf an den Felsen. Andere warfen die Geschöpfchen rücklings in den Fluss, wobei sie lachten und spotteten und wenn das Kind ins Wasser fiel, sagten sie: Du zappelst ja noch? ${ }^{37}$

Similar stereotypical notions are encountered in the representation of the traits of a foreign ethnic group. In an inscription of the Sumerian king, Utuhengal (2050 B.C.E.), the Gutians are accused of several misdemenours, one of which is their brute handling of their children and their women:

Gutium, Drachen des Gebirges, das die Hand gegen die Götter erhoben hat, das Sumers Königtum in die Berge verschleppt und Sumer mit Feindschaft angefüllt hatte, das dem Gatten die Gattin raubte, das den Eltern die Kinder entriss, das im Lande Hass und Feindschaft zeugte ... ${ }^{38}$

The topos of violence against children and their mothers also appears elsewhere in the ANE as an integral part of disaster scenarios ("Notzeitsschilderungen)." 39 The first instance of this motif can be traced back to a curse in

37 Anja Bröchler, "Was uns das Recht unseres Glaubens erlaubt zu tun: Kriegsgreuel in den Eroberungen Amerikas," in Kriegsgreuel: Die Entgrenzung der Gewalt in kriegerischen Konflikten vom Mittelalter bis ins 20. Jahrhundert (ed. Sönke Neitzel and Daniel Hohrath; KG 40; Padernborn: Ferdinand Schöningh, 2008), 137.

38 Wolfgang Röllig, “'Drachen des Gebirges': Fremde als Bedrohung in Mesopotamien," in Töten im Krieg (ed. Heinrich von Stietencron and Jörg Rüpke; München: Karl Alber, 1995), 87.

39 Thomas Podella, "Notzeit-Mythologem und Nichtigkeitsfluch," in Religionsgeschichtliche Beziehungen zwischen Kleinasien, Nordsyrien und dem Alten Testament (ed. Bernd Janowski, Klaus Koch and Gernot Wilhelm; OBO 129; Freiburg: Universitätsverlag, 1993), 427-454; see also Paul A. Kruger, "Disaster and the Topos of the World Upside Down: Selected Cases from the Ancient Near 
the Sumerian The Curse of Agade (Ur III period, 2100-2000 B.C.E.). ${ }^{40}$ This composition paints the contours of a crisis situation and resorts to all sorts of absurd imagery to contrast normal with abnormal cultural conventions. ${ }^{41}$ Essentially ordinary forms of behaviour are given an unfamiliar twist, also as far as the attitude towards women and children is concerned: "May the . . cattle slaughterer slaughter his wife, may your . . . sheep butcher butcher his child!"42 An identical theme is echoed in an Old Babylonian balag lament, reminding one of what is prophesised in Hos 10:14: "the mother is smashed in pieces upon (על) the children." This Babylonian balag proclaims that in turbulent times even the honoured mother goddess, Aruru, unexpectedly turns against her own creation: "Du ([Muttergöttin] Aruru) hast die Hürde zerstört, die Kühe wurden von Dir vernichtet. Du hast den Pferch zerstört, die Schafe wurden von Dir vernichtet. Sogar Kinder und Schwangere wurden übereinander gehäuft." 43

Another example, in the same vein, hails from the Egyptian The Admonitions of Ipuwer (4.3), and just as in the just mentioned Babylonian balag, disaster overrides all ethical limits: "Forsooth, the children of princes are dashed against the walls." 44 Much later Homer links up with this same tradition in The Iliad when describing the lament of King Priam of Troy over his

Eastern World," in Disaster and Relief Management: Katastrophen und ihre Bewältigung (ed. Angelika Berlejung; FAT 81; Tübingen: Mohr Siebeck, 2012), 391-424.

40 For resemblances in literary motifs between the The Curse of Agade, the city laments and the balag laments, see Jerrold Cooper, The Curse of Agade (Baltimore: Johns Hopkins University Press, 1983), 20ff; Piotr Michalowski, The Lamentation over the Destruction of Sumer and Ur (Winona Lake: Eisenbrauns, 1989), 8f; Frederick W. Dobbs-Allsopp, Weep, O Daughter of Zion: A Study of the City-Lament Genre in the Hebrew Bible (BibOr 44; Rome: Biblical Institute, 1993), 20.

41 For more examples of this notion of disaster in ANE texts, especially in lamentation literature, see Kruger, "Disaster," 395-413.

42 See Jeremy A. Black, et al., "The Cursing of Agade: Translation," lines 237-238, in The Electronic Text Corpus of Sumerian Literature (Oxford 1998-2000), n.p. [cited 24 November 2015], (ed. Jeremy A. Black, et al.). Online: http://wwwetcsl.orient.ox.ac.uk/section2/tr215.htm. See also Michel, Gott und Gewalt, 202; see also Konrad Volk, "Von Findel-, Waisen-, verkauften und deportierten Kindern: Notizen aus Babylonien und Assyrien," in "Schaffe mir Kinder ...": Beiträge zur Kindheit im alten Israel und in seinen Nachbarkulturen (ed. Andreas Kunz-Lübcke and Rüdiger Lux; ABG 21; Leipzig: Evangelische Verlagsanstalt, 2006), 74.

43 For the translation, see Volk, "Von Findel-," 74.

44 Lux, "Die Kinder auf der Gasse," 205, nr. 41. Erika Feucht, Das Kind im Alten Ägypten: Die Stellung des Kindes in Familie und Gesellschaft nach altägyptischen Texten und Darstellungen (Frankfurt: Campus Verlag, 1995), 367, nr. 1827 was the first to draw attention to this motif in the Egyptian literature (The Admonitions of Ipuwer 4:3-4:4). 
fallen city at the hands of the Achaians (22.58ff.), and again what happened to the children and wives is of central significance:

Oh, take pity on me, the unfortunate still alive, still sentient but illstarred, whom the father, Kronos' son, on the threshold of old age will blast with hard fate, after I have looked upon evils and seen my sons and my daughters dragged away captive and the chambers of marriage wrecked and innocent children taken and dashed to the ground in the hatefulness of war, and the wife of my sons dragged off by the accursed hands of the Achaians ... ${ }^{45}$

Against this backdrop the HB topoi of "the ripping open pregnant women" (Amos 1:13), and its closely associated "dashing in pieces the little ones" could hopefully be understood more clearly. In line with the examples cited above, these announcements most likely draw on a common literary repertoire in order to convey "unspeakable war traumas" ("unaussprechliche Kriegstraumatisierungen"). ${ }^{46}$ The focus is not so much on the historical verifiability of these portrayals, but on their immense psychological impact. Or phrased in the words of Smith-Christopher:

... to read stereotypical language of the Bible in reference to suffering - and particularly the suffering involved in siege warfare - as a measure not so much of the historical details of the disaster or catastrophe, but rather as a measure of the emotional, social, and obviously therefore spiritual impact of the disaster . . . ${ }^{47}$

\section{CONCLUSION}

This contribution approaches the brutal war themes of "ripping open of pregnant women" and the related "dashing in pieces the little ones" not primarily as reflections of a historical reality, but rather as topoi serving first and foremost a rhetorical aim. The fixed form of these motifs in a variety of ANE contexts and genres most probably affirms their literary character, viz., to amplify the extent and magnitude of a given disaster scene. In the words of Kern:

That these atrocities against women and children occurred mostly in prophecies and curses rather than in narratives of events, as well as their formulaic form, makes it difficult to conclude that such horrors were a common part of siege warfare. Rape was certainly common,

45 Kern, Ancient Siege Warfare, 1-2.

46 "In diesem Sinne könnten die Textstellen vom Aufschneiden schwangerer Frauen und vom Zerschmettern (klein[st]er) Kinder, welche die beiden Kriegsgräuel mehrfach zusammen und in zumeist sehr ähnlichen Worten festhalten, stellvertretend für weitere unaussprechliche - aber gleichwohl tatsächlich von Menschen erlittene Kriegstraumatisierungen stehen." See Poser, Das Ezechielbuch, 198.

${ }^{47}$ Daniel L. Smith-Christopher, A Biblical Theology of Exile (Minneapolis: Fortress Press, 2002), 104; see also also Poser, Das Ezechielbuch, 198, n. 297. 
112 Kruger, "Mothers and their Children," OTE 29/1 (2016): 100-115

and I think we must assume that smashing babies' heads and ripping open pregnant women were not unknown. But they seem to function in our sources as images reflecting a vision of a world without limits or structure or morality ... ${ }^{48}$

\section{BIBLIOGRAPHY}

Albenda, Pauline. "Woman, Child, and Family: Their Imagery in Assyrian Art." Pages 17-21 in La Femme dans le Proche-Orient Antique: Compte Rendu de la XXXIII Rencontre Assyriologique Internationale (Paris, 7-10 Juillet 1986). Edited by Jean-Marie Durand. Paris: Editions Recherche sur les Civilisations, 1986.

Ameling, Walter. "Tyrannen und schwangere Frauen.” Historia 45 (1986): 507-8.

Black, Jeremy A., Graham Cunningham, Esther Flückiger-Hawker, Eleanor Robson, and Gabor Zólyomi, eds. "The Cursing of Agade: Translation." Lines 237-238 in The Electronic Text Corpus of Sumerian Literature. Oxford 1998-2000. No Pages. Cited 24 November 2015. Edited by Jeremy A. Black, Graham Cunningham, Esther Flückiger-Hawker, Eleanor Robson, and Gabor Zólyomi. Online: http://www-etcsl.orient.ox.ac.uk/section2/tr215.htm.

Bar-Efrat, Shimon. "Love of Zion: A Literary Interpretation of Psalm 137." Pages 311 in Tehillah le-Moshe: Biblical and Judaic Studies in Honor of Moshe Greenberg. Edited by Mordechai Cogan, Barry L. Eichler and Jeffrey H. Tigay. Winona Lake: Eisenbrauns, 1997.

Berges, Ulrich and Bernd Obermayer. "Gottes Gewalt gegen Kinder in den Büchern Jesaja und Klagelieder: Eine Bibeltheologische Problemanzeige." Pages 53-75 in Gewalt im Spiegel alttestamentlicher Texte. Edited by Norbert C. Baumgart and Martin Nitsche. Erfurter Theologische Schriften 43. Würzburg: Echter Verlag, 2012.

Berlejung, Angelika. "Erinnerungen an Assyrien in Nahum 2, 4-3, 19." Pages 323356 in Die unwiderstehliche Wahrheit: Studien zur alttestamentlichen Prophetie: Festschrift für Arndt Meinhold. Edited by Rüdiger Lux and ErnstJoachim Waschke. Arbeiten zur Bibel und ihrer Geschichte 23. Leipzig: Evangelische Verlagsanstalt, 2006.

Borger, Rykle. Beiträge zum Inschriftenwerk Assurbanipals. Wiesbaden: Harrassowitz, 1996.

Botterweck, G. Johannes And Helmer Ringgren, eds. Theologisches Wörterbuch zum Alten Testament. Volume 5. Stuttgart: Kohlhammer, 1987.

Bröchler, Anja. “'Was uns das Recht unseres Glaubens erlaubt zu tun': Kriegsgreuel in den Eroberungen Amerikas." Pages 137-154 in Kriegsgreuel: Die Entgrenzung der Gewalt in kriegerischen Konflikten vom Mittelalter bis ins 20. Jahrhundert. Edited by Sönke Neitzel and Daniel Hohrath. Krieg in der Geschichte 40. Padernborn: Ferdinand Schöningh, 2008.

Cogan, Mordechai. “'Ripping Open Pregnant Women' in Light of an Assyrian Analogue." Journal of the American Oriental Society 103/4 (1983): 755-757.

Cogan, Mordechai and Hayim Tadmor. II Kings: A New Translation with Introduction and Commentary. The Anchor Bible 11. New York: Doubleday, 1988.

${ }^{48}$ Kern, Ancient Siege Warfare, 85 ; italics added. 
Cooper, Jerrold S. The Curse of Agade. Baltimore: Johns Hopkins University Press, 1983.

Dobbs-Allsopp, Frederick W. Weep, O Daughter of Zion: A Study of the CityLament Genre in the Hebrew Bible. Biblica et Orientalia 44. Rome: Biblical Institute, 1993.

Dubovský, Peter. "Ripping Open Pregnant Arab Women: Reliefs in Room L of Ashurbanipal's North Palace." Orientalia (NS) 78 (2009): 394-419.

Feucht, Erika. Das Kind im Alten Ägypten: Die Stellung des Kindes in Familie und Gesellschaft nach altägyptischen Texten und Darstellungen. Frankfurt: Campus Verlag, 1995.

Fritz, Volkmar. "Die Fremdvölkersprüche des Amos." Vetus Testamentum 37/1 (1987): 26-38.

Gammie, John G. "Herodotus on Kings and Tyrants: Objective Historiography or Conventional Portraiture.” Journal of Near Eastern Studies 45/3 (1986): 171195.

Gass, Erasmus. Die Moabiter: Geschichte und Kultur eines ostjordanischen Volkes im 1. Jahrtausend v. Chr. Abhandlungen des Deutschen Palästina-Vereins 38. Wiesbaden: Harrassowitz, 2009.

Glenny, W. Edward. Finding Meaning in the Text: Translation Technique and Theology in the Septuagint of Amos. Supplements to Vetus Testamentum 126. Leiden: Brill, 2009.

Grayson, A. Kirk. Assyrian Rulers of the Early First Millennium BC I (1114-859 BC). The Royal Inscriptions of Mesopotamia, Assyrian Periods 2. Toronto: University of Toronto Press, 1991.

Hasel, Michael G. "Assyrian Military Practices and Deuteronomy's Laws of Warfare." Pages 67-81 in Writing and Reading War: Rhetoric, Gender, and Ethics in Biblical and Modern Contexts. Edited by Brad E. Kelle and Frank R. Ames. Society of Biblical Literature Symposium Series 42. Atlanta: Society of Biblical Literature, 2008.

Japhet, Sara. 1 Chronik. Herders Theologischer Kommentar zum Alten Testament. Freiburg: Herder, 2002.

Kern, Paul B. Ancient Siege Warfare. Bloomington: Indiana University Press, 1999.

Knoppers, Gary N. 1 Chronicles 10-29. The Anchor Bible 12a. New York: Doubleday, 2004.

Kruger, Paul A. "Disaster and the Topos of the World Upside Down: Selected Cases from the Ancient Near Eastern World." Pages 391-424 in Disaster and Relief Management: Katastrophen und ihre Bewältigung. Edited by Angelika Berlejung. Forschungen zum Alten Testament 81. Tübingen: Mohr Siebeck, 2012. . "Women and War Brutalities in the Minor Prophets: The Case of Rape." Old Testament Essays 27/1 (2014): 147-176.

Lambert, Wilfred G. "A Neo-Babylonian Tammuz Lament." Journal of the American Oriental Society 103/1 (1983): 211-215.

Lux, Rüdiger. "Die Kinder auf der Gasse: Ein Kindheitsmotiv in der prophetischen Gerichts- und Heilsverkündigung." Pages 197-221 in "Schaffe mir Kinder ...": Beiträge zur Kindheit im alten Israel und in seinen Nachbarkulturen. Edited by 
114 Kruger, "Mothers and their Children," OTE 29/1 (2016): 100-115

Andreas Kunz-Lübcke and Rüdiger Lux. Arbeiten zur Bibel und ihrer

Geschichte 21. Leipzig: Evangelische Verlagsanstalt, 2006.

Mayer, Walter. "Die Zerstörung des Jerusalemer Tempels 587 v.Chr. im Kontext der

Praxis von Heiligtumszerstörungen im antiken Vorderen Orient." Pages 1-22 in

Zerstörungen des Jerusalemer Tempels: Geschehen-Wahrnehmung-

Bewältigung. Edited by Johannes Hahn. Wissenschaftliche Untersuchungen

zum Neuen Testament 147. Tübingen: Mohr Siebeck, 2002.

. "Gedanken zur Deportation im Alten Orient." Pages 215-232 in Macht und

Herrschaft. Edited by Christian Sigrist. Alter Orient und Altes Testament 316.

Münster: Ugarit-Verlag, 2004.

Michalowski, Piotr. The Lamentation over the Destruction of Sumer and Ur. Winona Lake: Eisenbrauns, 1989.

Michel, Andreas. Gott und Gewalt gegen Kinder im Alten Testament. Forschungen zum Alten Testament 37. Tübingen: Mohr Siebeck, 2003. . "Gewalt gegen Kinder im alten Israel: Eine sozialgeschichtliche Perspektive." Pages 137-163 in "Schaffe mir Kinder ...": Beiträge zur Kindheit im alten Israel und in seinen Nachbarkulturen. Edited by Andreas Kunz-Lübcke and Rüdiger Lux. Arbeiten zur Bibel und ihrer Geschichte 21. Leipzig: Evangelische Verlagsanstalt, 2006.

. "Texts of Terror für Alte? Gewalt gegen ältere Menschen im Alten Testament." Pages 53-82 in Macht-Gewalt-Krieg im Alten Testament: Gesellschaftliche Problematik und das Problem ihrer Repräsentation. Edited by Irmtraud Fischer. Quaestiones Disputatae 254. Freiburg: Herder, 2013.

Nadali, Davide and Jordi Vidal.The Other Face of the Battle: The Impact of War on Civilians in the Ancient Near East. Alter Orient und Altes Testament 413. Münster: Ugarit-Verlag, 2014.

Neumann, Hans, Reinhard Dittmann, Susanne Paulus, Georg Neumann and Anais Schuster-Brandis. Krieg und Frieden im Alten Vorderasien: 52e Rencontre Assyriologique Internationale: International Congress of Assyriology and Near Eastern Archaeology, Münster, 17.-21. Juli 2006. Alter Orient und Altes Testament 401. Münster: Ugarit-Verlag, 2014.

Oppenheim, A. Leo."Siege-Documents from Nippur.” Iraq 17 (1955): 69-89. Parpola Simo and Kazuko Watanabe. Neo-Assyrian Treaties and Loyalty Oaths. State Archives of Assyria 2. Helsinki: Helsinki University Press, 1988.

Podella, Thomas. "Notzeit-Mythologem und Nichtigkeitsfluch." Pages 427-454 in Religionsgeschichtliche Beziehungen zwischen Kleinasien, Nordsyrien und dem Alten Testament. Edited by Bernd Janowski, Klaus Koch and Gernot Wilhelm. Orbis biblicus et orientalis 129. Freiburg: Universitätsverlag, 1993.

Poser, Ruth. Das Ezechielbuch als Trauma-Literatur. Supplements to Vetus Testamentum 154. Leiden: Brill, 2012.

Risse, Siegfried. "'Wohl dem, der deine kleinen Kinder packt und sie am Felsen zerschmettert': Zur Auslegungsgeschichte von Ps 137,9.” Biblical Interpretation 14/4 (2006): 364-384.

Röllig, Wolfgang. “'Drachen des Gebirges': Fremde als Bedrohung in Mesopotamien." Pages 87-97 in Töten im Krieg. Edited by Heinrich von Stietencron and Jörg Rüpke. München: Karl Alber, 1995. 
Rollinger, Robert. "Herodotus, Human Violence and the Ancient Near East." Pages 121-150 in The World of Herodotus. Edited by Vassos Karageorghis and Ioannes Taifacos. Nicosia: Kailas, 2004.

Schwartz, Daniel R. 2 Maccabees. Commentaries on Early Jewish Literature. Berlin: De Gruyter, 2008.

Schwyn, Irène. "Kinder und ihre Betreuungspersonen auf den neuassyrischen Palastreliefs." Pages 323-330 in Images and Gender: Contributions to the Hermeneutics of Reading Ancient Art. Edited by Silvia Schroer. Orbis biblicus et orientalis 220. Fribourg: Academic Press, 2006.

Smith-Christopher, Daniel L. A Biblical Theology of Exile. Minneapolis: Fortress Press, 2002.

Staubli, Thomas. Das Image der Nomaden im Alten Israel und in der Ikonographie seiner sesshaften Nachbarn. Orbis biblicus et orientalis 107. Fribourg: Academic Press, 1991.

Tadmor, Hayim. The Inscriptions of Tiglath-Pileser III, King of Assyria: Critical Edition, with Introduction, Translations and Commentary. Jerusalem: The Israel Academy of Sciences and Humanities, 1994.

Tadmor, Hayim and Shigeo Yamada. The Royal Inscriptions of Tiglath-Pileser III (744-727 BC) and Shalmaneser V (726-722 BC), Kings of Assyria. The Royal Inscriptions of the Neo-Assyrian Period 1. Eisenbrauns: Winona Lake, 2011.

Tuor-Kurth, Christina. Kindesaussetzung und Moral in der Antike: Jüdische und christliche Kritik am Nichtaufziehen und Töten neugeborener Kinder. Forschungen zur Kirchen- und Dogmengeschichte 101. Göttingen: Vandenhoeck \& Ruprecht, 2010.

Volk, Konrad. "Von Findel-, Waisen-, verkauften und deportierten Kindern: Notizen aus Babylonien und Assyrien." Pages 47-87 in "Schaffe mir Kinder ...":

Beiträge zur Kindheit im alten Israel und in seinen Nachbarkulturen. Edited by Andreas Kunz-Lübcke and Rüdiger Lux. Arbeiten zur Bibel und ihrer Geschichte 21. Leipzig: Evangelische Verlagsanstalt, 2006.

Werner, Herbert. Amos. Exempla Biblica 4. Göttingen: Vandenhoeck \& Ruprecht, 1969.

Paul A. Kruger, Department of Ancient Studies, University of Stellenbosch, Private Bag X1, Matieland, 7602.Email: pak@sun.ac.za 